\title{
Cost-effective assessment of conservation status of fens
}

\author{
Dagmar K. Andersen, Bettina Nygaard, Jesper R. Fredshavn \& Rasmus Ejrnæs
}

\section{Keywords}

Accuracy; Calcareous fens; Denmark; EC Habitats Directive; Indicator values; Nutrient ratio; Precision; Typical species; Wetlands

\section{Abbreviations \\ E-light Ellenberg indicator values for light; E-nutrient nitrogen; E-reaction soil reaction; E-moisture moisture \\ Nomenclature \\ Frederiksen et al. (2006) and Stenberg \& Mossberg (2005) for vascular plants; Hallingbäck \& Holmåsen (2000) and Smith (2004) for bryophytes \\ Received 24 August 2011 \\ Accepted 8 November 2012 \\ Co-ordinating Editor: Kris Verheyen}

Andersen, D.K. (corresponding author, dagmar.andersen@biology.au.dk) \& Nygaard, B. (bny@dmu.dk) \& Fredshavn, J.R. (jrf@dmu.dk) \& Ejrnæs, R. (rej@dmu.dk): Institute of Bioscience, Aarhus University, Grenaavej 12, 8410, Roende, Denmark

\begin{abstract}
Questions: How can conservation status of rich fen and alkaline spring areas be assessed most cost-effectively based on existing monitoring data? What is the precision and accuracy of available indicators?
\end{abstract}

Location: Rich fen and alkaline spring areas in Denmark.

Methods: Potential indicators of conservation status were evaluated based on: accuracy, measured as the ability to predict the number of typical species in monitoring plots; precision, measured as variation over years of indicators in repeated plots; and cost of obtaining data for the indicator. Indicators were derived using data from the Danish National Monitoring and Assessment Programme for the Aquatic and Terrestrial Environment from 2000 to 2009. Indicators included biotic indices derived from species lists, abiotic measurements of $\mathrm{pH}$ and nutrients and structural measurements of vegetation height and tree cover.

Results: The majority of indicators showed a significant correlation with the number of typical species. Floristic indicators, especially based on Ellenberg nutrient values, showed superior correlation and were furthermore very stable over years. Structural indicators were generally accurate, but were highly imprecise with high between-year variation. Among the abiotic indicators, $\mathrm{pH}$ and soil $\mathrm{P}$ were inaccurate, whereas tissue $\mathrm{N}$ content and nitrate in water were accurate but with low precision. When balancing efficiency of indicators with monitoring costs, laboratory analyses stand out as expensive compared to recording of a species list, the latter providing up to five valuable indicators.

Conclusions: Floristic indicators derived from Ellenberg values, and especially those related to nutrient availability, are cost-effective indicators of conservation status. The method is applicable to all regions where Ellenberg indicator values have been calibrated to fit local conditions.

\section{Introduction}

The aim of the EC Habitats Directive is to maintain or restore biodiversity and achieve 'favourable conservation status' of natural habitats and the wild flora and fauna (EC Habitats Directive 1992). Rich fens and alkaline springs are both habitat types on the EC Habitats Directive. Rich fens are among the most species-rich ecosystems of the temperate zone and host many endangered species, and phosphorus-limited habitats are especially rich in rare species (Wassen et al. 2005).

Rich fens and alkaline springs to a great extent overlap (Wheeler \& Proctor 2000) and share important characteristics, most notably a continuous inflow of nutrient-poor groundwater creating a stable water table throughout the year (Boeye \& Verheyen 1992; Almendinger \& Leete 1998a; Amon et al. 2002). The continuous supply of calcium-rich groundwater maintains a circum-neutral $\mathrm{pH}$ between 5.5 and 7.4 (Boyer \& Wheeler 1989; Almendinger $\&$ Leete 1998b). Furthermore, the water has a high saturation of bases such as $\mathrm{Mg}$, Fe and $\mathrm{Ca}$, which are important in immobilizing phosphorus $(\mathrm{P})$. Phosphorus is bound in complex structures to $\mathrm{Fe}, \mathrm{Ca}$ and $\mathrm{Mg}$ making its availability very low (Bedford et al. 1999; Wassen et al. 2005; Boomer \& Bedford 2008).

Lowering of the water table caused by drainage or water extraction will lead to extinction of the rich fen bryophytes and other plant species restricted to wet habitats. Unless 
drainage is followed by eutrophication, the habitat may remain species-rich but without the characteristic bryophytes (Grootjans et al. 2006; Mälson et al. 2007). However, drainage of previously undrained peat soils is likely to induce acidification and internal eutrophication involving the release of $\mathrm{SO}_{4}-\mathrm{S}, \mathrm{NH}_{4}-\mathrm{N}, \mathrm{Ca}, \mathrm{Mg}, \mathrm{NO}_{3}-\mathrm{N}$ and soluble reactive $\mathrm{P}$ (Heathwaite 1990; van Haesebroeck et al. 1997). Drainage also induces rapid mineralization of the peat followed by mobilization of nutrients and eutrophication (Grootjans et al. 2006; Wassen \& Olde Venterink 2006).

External eutrophication is also a major threat to most natural, herb-dominated habitats in Western Europe. Eutrophication by air-borne or water-carried nutrients has a huge potential to change the composition and productivity of the vegetation (Bedford et al. 1999; Wassen et al. 2005). Alkaline fens and springs are characterized by slowgrowing, stress-tolerant species and are particularly vulnerable to elevated nutrient levels.

According to Article 17 of the Habitats Directive, all member states are obliged to report to the EC Council the status of the protected habitats every 6 yrs. A favourable conservation status must be based on several criteria: area and distribution of the habitat type must be stable or increasing; structure and function of the habitat must be considered favourable; and presence of typical species of the habitats must be stable or increasing (EC Habitats Directive 1992). While the area and distribution is easily interpreted, there is an obvious need for development of cost-effective indicators that reflect structure and function as well as the fate of typical species. To meet the obligations of the EC legislation, Denmark has implemented a Danish National Monitoring and Assessment Programme for the Aquatic and Terrestrial Environment, the NOVANA programme (Svendsen and Norup 2005), which covers a large number of the habitats listed in Annex I of the Habitats Directive (EC Habitats Directive 1992). The monitoring programme includes stratified random sampling in predefined monitoring stations of vegetation as well as structural parameters, such as vegetation height and cover of trees, and, in a subset of plots, abiotic parameters such as soil, water and plant tissue chemistry (Svendsen and Norup 2005). Monitoring has taken place every year from 2004 to 2009. The programme is based on budgets using averaged time consumption and cost of laboratory analysis, calculated on the basis of empirical experience and monitoring tests. This offers a unique opportunity to evaluate the cost-efficiency of the monitoring parameters acting as potential indicators of conservation status.

The objective of this study is to evaluate the cost-efficiency of indicators for conservation status derived from data from the NOVANA programme based on accuracy, precision and cost. Accuracy is here defined as the close- ness of the indicator value to the true value (represented by number of typical species), whereas precision is reproducibility or closeness of agreement obtained through replicated measurements (ISO/IEC Guide 99-12 2007). Indicators belong to one of three categories: (1) structural parameters (vegetation height and cover of trees), (2) abiotic measurements ( $\mathrm{pH}$, content of nitrate in soil water, tissue $\mathrm{N}$ content of bryophytes and plant-available soil P), (3) floristic indicators derived from species lists (the number of typical species present, Ellenberg indicator values for moisture (E-moisture), light (E-light), N (E-nutrient) and soil reaction (E-reaction), and composite indicators of E-nutrient and E-reaction.

Ellenberg indicator values as an indirect measure of ecological parameters such as soil fertility, moisture and $\mathrm{pH}$ are widely used, and the reliability of these indicator values has been discussed thoroughly (e.g. Ter Braak $\&$ Gremmen 1987; Diekmann 1995; Schaffers \& Sýkora 2000; Nimis \& Martellos 2001; Wamelink et al. 2002). Indicator values are frequently used for analysing environmental changes (e.g. Leith et al. 2005; Seidling 2005; Large et al. 2007); however, no studies have used the indicator values to link directly to conservation status. We use the number of typical species as a measure of conservation status, since a habitat with long continuity of stable inflow of nutrient-poor, base-rich groundwater should promote species typical of the habitat. The number of typical species in a monitoring plot is thus both the first candidate for a cost-effective indicator, but it is also the scale against which the effectiveness of the other potential indicators is evaluated.

\section{Methods}

Data

All records from the NOVANA programme (Svendsen et al. 2005) where the plot was classified in the field as rich fen, alkaline spring or floating fen were selected (6746 records). Plots without bryophyte species were excluded to ensure a specific level of vegetation recording. Floating fens were included since the classification of that habitat is based on structural features and the vegetation can be dominated by rich fen species or species typical of more acidic habitats, depending on the water source. In order to exclude acidic floating fens, plots with an average E-reaction value $<4.5$ were excluded, leaving 4154 plots from 152 monitoring stations (see Fig. 1 for distribution map of monitoring stations).

While alkaline springs are mainly defined by visible moving surface water, rich fens are mainly recognized by their characteristic species composition. The discrimination between springs and fens is not always evident, and species from alkaline fens, especially bryophytes, are very likely to also occur in springs. In Denmark, rich fen has been 


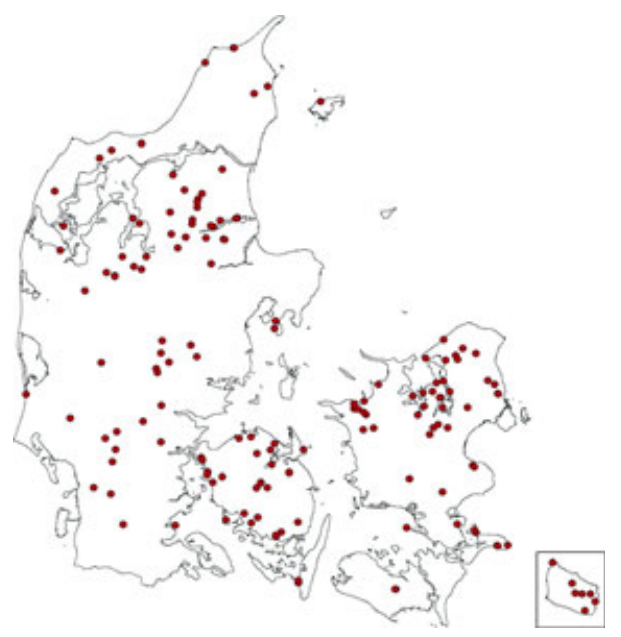

Fig. 1. Distribution of the 152 monitoring stations from the Danish Monitoring Programme included in the study. Plots or monitoring station are classified as alkaline spring, floating fen or rich fen.

interpreted in a very broad sense including all the CORINE biotopes (Anon 1991) referred to in the interpretation manual of the Habitats Directive (Council of European Communities 1999). Rich fens thus include most fen vegetation influenced by groundwater seepage, but also subtypes of CORINE mentioned in the Interpretation Manual (Anon 1991) were included, as well as fens in suboptimal conservation status that are transitional to wet meadows and tall herb fens (Anon 1991). This selection provided a data set with a conspicuous gradient in conservation status.

\section{Field and laboratory measurements}

The species lists and characterization of vegetation structure were derived from monitoring plots of $78.5 \mathrm{~m}^{2}$ (a circle with radius $=5 \mathrm{~m}$ ), which had been monitored one to six times during the period 2004-2009. All plots were marked for GPS position, with an uncertainty of up to $10 \mathrm{~m}$ (Schwieger 2003). Monitoring included recording of all plant species, measurements of vegetation height and subjective estimation of tree cover and shrubs above and below 1-m tall. In a subset of plots, chemical measurements accompanied the vegetation data:

- Nitrate $\mathrm{N}$ content in water was measured in 518 plots (35\% of all plots classified as alkaline spring; water samples were not taken in rich fens). The nitrate $\mathrm{N}$ content was analysed with ion chromatography or flow injection analysis. The sample was injected in a stream of ammonium chloride and passed over a cadmium reactor, where nitrate was reduced to nitrite. Nitrite was reacted with sulphanilamide and naphtylethylenedi- amine and the resulting azo-colour was spectrophotometrically determined at $540 \mathrm{~nm}$.

- Total N content in bryophyte tissue was measured in 997 plots (24\% of all plots) using a LECO CNS-2000 analyser (Eurofins, Vejen, Denmark). Dried plant material was incinerated at $1100{ }^{\circ} \mathrm{C}$. After measuring $\mathrm{CO}_{2}$, using infrared spectroscopy, N oxides were reduced to $\mathrm{N}$ using a copper catalyst, and $\mathrm{CO}_{2}$ was removed by absorption before measuring $\mathrm{N}$ in a thermal conductivity cell.

- Soil P was measured in 331 plots (10\% of all plots in rich fen). The soil was extracted with $0.5 \mathrm{M}$ sodium hydrogen carbonate and plant available phosphate was estimated using spectrophotometry. The value was only measured once during the period, hence, we could not evaluate the year-to-year variation.

- $\mathrm{pH}$ in rich fen soil as well as floating fen and spring water was measured in 1182 plots (28\% of all plots). In fens, $\mathrm{pH}$ was measured in a $0.01 \mathrm{M} \mathrm{CaCl}_{2}$ suspension of the substrate with a combination glass electrode at $21{ }^{\circ} \mathrm{C}$. For springs and floating fens, $\mathrm{pH}$ in water was measured in the field with a combination glass electrode.

\section{Typical species}

The typical species are part of the definition of conservation status of habitats in the Habitats Directive. The directive provides no authoritative list of typical species, rather Member States were asked to provide lists of typical species from their territories for each habitat type as part of the reporting of conservation status in 2007. Denmark did not report such lists. Therefore, we used a compiled list of potential typical species from lists in the interpretation manual of the Habitats Directive (EC Habitats Directive 1992) and the corresponding CORINE biotopes (Anon 1991) supplemented with species from Nordic habitats (Påhlsson 1994) referred to in the Interpretation manual (Council of European Communities 1999). The final lists appear in Ejrnæes et al. (2009). As the lists were derived from the list of characteristic species, they include both rather common species expected in most habitats and less common species expected only in habitats of high conservation value (Appendix S1). Some of the common species are not restricted to fens and springs, e.g. Briza media in grassland, Potentilla erecta in grassland, heathland and poor fen and Carex nigra in meadow and moist grassland (Ejrnæes et al. 2009).

\section{Selection of indicators for evaluation}

Indicators were selected based on their potential to reflect the properties of rich fen and alkaline spring in favourable conservation status, i.e. low-nutrient status and natural hydrology. The selected indicators may be divided in 
abiotic indicators derived from chemical analyses of soil and water, floristic indicators derived from the lists of plant species, and structural indicators derived from the structural measurements in plots.

Abiotic indicators comprise tissue $\mathrm{N}$, water $\mathrm{NO}_{3}$, soil $\mathrm{P}$ and $\mathrm{pH}$, measured directly during analysis of soil, water and plant tissue. Floristic indicators comprise number of typical species and mean Ellenberg numbers reflecting plant preferences according to gradients in soil moisture (E-moisture), $\mathrm{N}$ (E-nutrient), soil pH (E-reaction) and light availability (E-light) (Ellenberg et al. 1991). We have studied previous suggestions and interpreted Ellenberg $\mathrm{N}$ as an indicator of soil fertility or potential productivity rather than N per se (Hill \& Carey 1997; Schaffers \& Sýkora 2000; Diekmann 2003). Ellenberg indicator values of $\mathrm{N}$ are not available for bryophytes; hence, mean values were calculated based on indicator values of vascular plants. Ellenberg numbers were used to indicate soil fertility and $\mathrm{pH}$ since chemical analyses of nutrient content of water, soil and plant tissue had only been measured in a subset of plots, and because nutrient availability is known to be difficult to estimate correctly from a single annual measurement (Hájek \& Hekera 2004). Ellenberg numbers referring to soil moisture and light were also included, potentially related to both hydrology and nutrient availability. Nutrient availability and $\mathrm{pH}$ are naturally correlated in many plant communities (Bridgham et al. 1996, 1998, 2001; Bragazza et al. 2002; Rozbrojová \& Hájek 2008) as are E-reaction and E-nutrient (Diekmann $\delta$ Falkengren-Grerup 1998; Seidling 2005). Hence, composite indicators of eutrophication were calculated by conditioning E-nutrient on E-reaction. The calculation of composite indicators took two approaches. First, E-nutrient was simply divided by E-reaction, referred to in the following as nutrient ratio. Second, the deviation from expected E-nutrient given E-reaction was calculated by regression modelling of E-nutrient as a function of E-reaction, allowing for a nonlinear relationship by inclusion of a quadratic term of E-reaction in the model. The residuals from the regression model were taken as an indicator of eutrophication and referred to in the following as residual $N$.

Finally, the structure of the vegetation was represented in the list of candidate indicators as the average vegetation height in the centre of the plot and as the percentage cover of woody species above and below $1-\mathrm{m}$ tall in the plot.

\section{Concept of evaluation}

Cost-efficiency of indicators was evaluated with reference to the following three criteria:

1. Accuracy: Effectiveness of the indicator to predict the number of typical species in a plot. This criterion was not relevant for the typical species indicator.
2. Precision: Variation of the indicators in plots repeated in different years.

3. Cost: The cost of collecting the indicator in the monitoring programme at plot level.

\section{Data analysis}

Composite indicators of eutrophication

The regression model of E-nutrient as a function of E-reaction included testing for the significance of a quadratic term in the model. After selecting the best model, the residuals were extracted from the model. The residuals corresponded to the deviation from expected E-nutrient, and were used in the following as a potential indicator of eutrophication.

\section{Accuracy}

Accuracy of indicators was investigated using Spearman's rank correlation between the 13 indicators and number of typical species. The analysis was performed on all plots, excluding repetitions, giving a total of 2179 records. We decided to use rank correlation statistics based on scatterplots indicating violation of normally distributed, homoscedastic errors. These plots were also used for interpretation of the shape of monotonous relationships revealed by rank correlation statistics (Appendix S3).

Averages of unweighted Ellenberg values for light, soil moisture, soil reaction and $\mathrm{N}$ were calculated for the 4173 plots using Ellenberg values calibrated to the British flora and environment (Hill et al. 1999). The British Ellenberg values were used since the Danish climate and soil are expected to be more similar to British conditions than to Middle European conditions. Further, Hill et al. (1999) included a larger proportion of the Danish species. Averaged Ellenberg numbers and typical species were both derived from the species lists, and are therefore not independent. To take this into account, we also tested the correlation after exclusion of the typical species from the calculation of Ellenberg values.

We took a univariate approach to the selection of indicators, but in order to investigate the co-variation between these and the consistency of our results across grouping variables (e.g. geographical region and wetland type), we used a multiple GLM with Poisson-distributed errors to investigate the combined effects of indicators on the number of typical species. We used standard statistical Chisquared tests as well as leave-one-out cross-validation to select the best GLM model.

\section{Precision}

Precision of the indicators was evaluated for plots with repeated measurements by calculating the percentage 
deviation of each record from the plot mean. These deviations were subsequently averaged over all plots for each indicator. The plots were repeated from two to six times and constitute 2661 records.

\section{Cost of measurements}

The calculation of indicator cost was based on the marginal labour cost of field recording of the indicator and the budget price of laboratory analysis in the monitoring period. The labour cost was ca. $55 € \cdot \mathrm{h}^{-1}$ and the laboratory prices were those used in the budget of the NOVANA programme 2010 (J. R. Fredshavn, unpubl. data). The average time consumed to record a full species list from a plot of $78.5 \mathrm{~m}^{2}$ was estimated to $40 \mathrm{~min}$, corresponding to $36 €$. The recording of vegetation height was estimated at $10 \mathrm{~min}$ $(9 €)$ and recording of tree cover at $5 \mathrm{~min}(5 €)$. The laboratory costs of $\mathrm{pH}, \mathrm{P}$ value, $\mathrm{NO}_{3}-\mathrm{N}$ and tissue $\mathrm{N}$ analysis, including 5-10 min sampling time, were estimated as 18 , 33, 42 and $92 €$, respectively.

All statistical analysis was performed with the statistical package $\mathrm{R}$ version 2.12.1 (R Foundation for Statistical Computing, Vienna, AT). Cross-validation was performed with the function 'cv.glm' in the 'boots' library.

\section{Results}

\section{Calculation of composite indicators of eutrophication}

Model selection in the regression model of E-nutrient as a function of E-reaction suggested a linear regression with a quadratic term added (Adj. $R^{2}=0.61, P<0.001$ ), of the form: $\quad$ E-nutrient $=13.5-4.6 *$ E-reaction $+0.5^{*} \mathrm{E}$-reaction $^{2}$. The indicator 'residual $\mathrm{N}^{\prime}$ is the model residuals, ranging from -1.5 to 1.4 .

The alternative composite indicator, 'nutrient ratio', is calculated as the ratio between E-nutrient and E-reaction, ranging from 0.5 to 1.0 .

Figure 2 illustrates the difference between the two composite indicators. The point cloud is the plots placed according to their mean values of E-reaction and E-nutrient, and the contour lines of the 4154 plots correspond to values of the resulting indicator. Within the domain of the point cloud, nutrient ratio does not follow the non-linearity of the point cloud at high $\mathrm{pH}$, as do residual $\mathrm{N}$ values.

\section{Accuracy}

Table 1 shows the rank correlation between typical species and indicators. The first column reveals high correlation coefficients - positive or negative - of Ellenberg indicators (except E-moisture), vegetation height and cover of trees $<$ l-m tall. The abiotic parameters correlate less with the number of typical species; tissue-N performing best, fol-
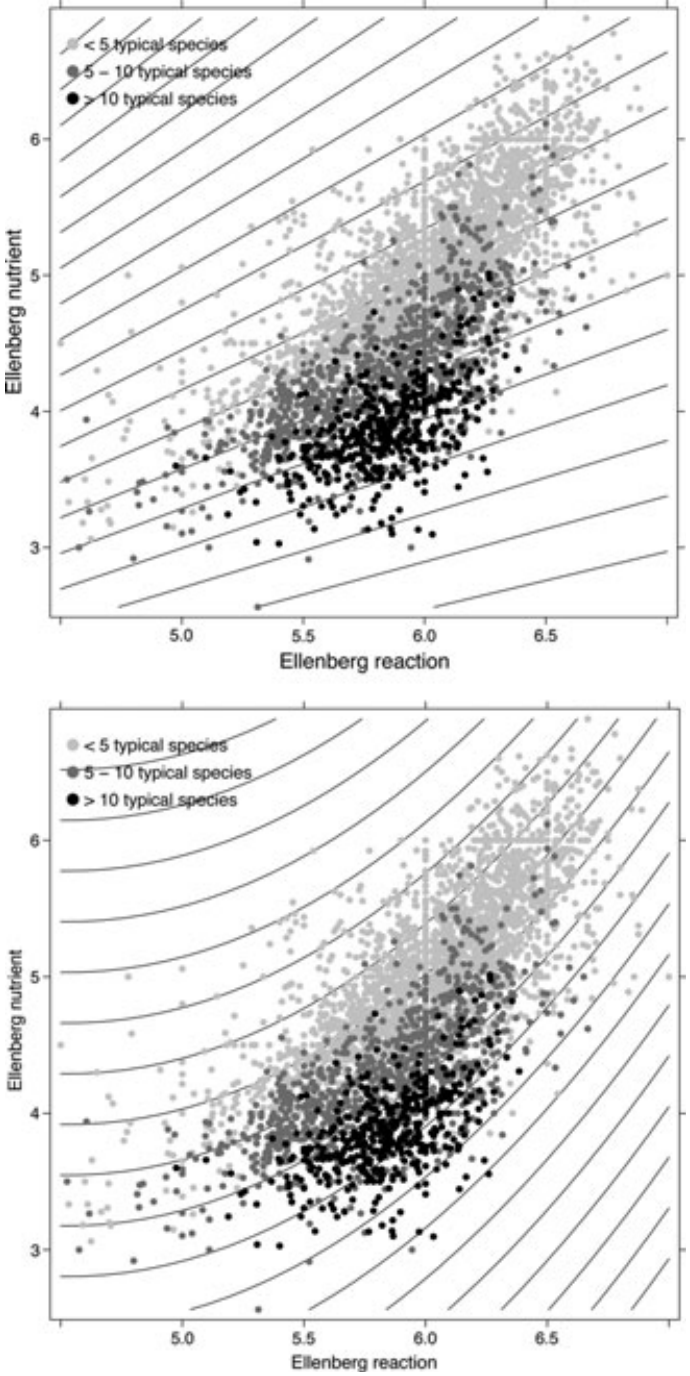

Fig. 2. Distribution of monitoring plots in relation to E-reaction and E-nutrient. Point colour illustrates the number of typical species recorded. Upper graph: Lines show the progress of nutrient ratio. Lower graph: Lines show the progress of the model 'residual N'.

lowed by nitrate in water. Soil $\mathrm{P}$ and $\mathrm{pH}$ have non-significant correlations with number of typical species. In general, the floristic indicators are more accurate than both abiotic and structural parameters, even after excluding the typical species from their calculation. Nutrient ratio performs best, followed by E-nutrient and residual N. Ellenberg indicators for light, soil reaction and moisture are also accurate, however, the last only correlates weakly $(P<0.05)$ and becomes insignificant after exclusion of the typical species. All correlation coefficients between indicators are shown in a correlation matrix in Appendix S2, and plots showing the distribution of the number of typical species in relation to the different indicators are shown in Appendix S3. 
Table 1. Mean value, range, correlation, variation and cost of all evaluated indicators. Spearman's rank correlation between indicators and number of typical species is calculated for species lists including and excluding the typical species

\begin{tabular}{|c|c|c|c|c|c|c|}
\hline Indicator & $\begin{array}{l}\text { Indicator } \\
\text { mean }\end{array}$ & $\begin{array}{l}\text { Indicator range } \\
\text { (Min; Max) }\end{array}$ & $\begin{array}{l}\text { Correlation (Inc. } \\
\text { typical species) }\end{array}$ & $\begin{array}{l}\text { Correlation (Exc. } \\
\text { typical species) }\end{array}$ & Variation & Cost/Sample \\
\hline \multicolumn{7}{|l|}{ Abiotic Indicators } \\
\hline Tissue $\mathrm{N}$ & 1.7 & $0.03 ; 26.4$ & $-0.22^{\star \star \star}$ & - & 16.7 & 92 \\
\hline Water $\mathrm{NO}_{3}^{-}$ & 2901.4 & $0 ; 34000$ & $-0.17^{\star}$ & - & 37.8 & 42 \\
\hline Soil P & 2.6 & $0 ; 17$ & $-0.08 \mathrm{~ns}$ & - & - & 33 \\
\hline $\mathrm{pH}$ & 6.4 & $3.6 ; 8.6$ & $0.009 \mathrm{~ns}$ & - & 3.0 & 18 \\
\hline \multicolumn{7}{|l|}{ Floristic Indicators } \\
\hline E-moisture & 7.5 & $5.0 ; 9.7$ & $0.05^{*}$ & $-0.05^{\star}$ & 2.3 & 36 \\
\hline E-light & 7.0 & $5.0 ; 7.7$ & $0.60 * * *$ & $0.44^{\star \star \star}$ & 0.9 & 36 \\
\hline E-nutrient & 4.7 & $2.9 ; 6.9$ & $-0.66^{\star * \star}$ & $-0.54^{\star \star \star}$ & 3.0 & 36 \\
\hline E-reaction & 5.9 & $4.5 ; 6.9$ & $-0.32^{\star \star \star}$ & $-0.27 * \star \star$ & 1.6 & 36 \\
\hline Nutrient Ratio & 0.8 & $0.5 ; 1.0$ & $-0.72^{\star \star *}$ & $-0.61 * * *$ & 2.4 & 36 \\
\hline Typical species Residual N & 0 & $-1.5 ; 1.4$ & $-0.63^{* * *}$ & $-0.54^{\star \star *}$ & - & 36 \\
\hline Structural indicators & & & & & 28.0 & 36 \\
\hline Vegetation Height & 39.6 & $0 ; 200$ & $-0.36^{\star \star \star}$ & - & 36.4 & 9 \\
\hline Trees Below 1 m & 1.7 & $0 ; 75$ & $0.30 * \star \star$ & - & 58.2 & 5 \\
\hline Trees above $1 \mathrm{~m}$ & 8.5 & $0 ; 80$ & $-0.17 * \star \star$ & - & 47.2 & 5 \\
\hline
\end{tabular}

Level of significance: ${ }^{\star \star \star} P<0.001,{ }^{\star} * P<0.01,{ }^{\star} P<0.05$, ns, not significant. Plot variation over years in percentage and absolute cost of measuring the indicator per sample measured in Euro.

The first multivariate GLM was built with all indicators above $5 \%$ significance level in the rank correlation test, entered in order of decreasing correlation. E-nutrient and residual $\mathrm{N}$ were excluded based on the high correlation with the nutrient ratio (Appendix S2). Based on diagnostic plots, model residuals were judged to be approximately normal with homoscedastic variance. The summary statistics revealed that after fitting nutrient ratio $(P<0.001)$, only vegetation height remained significant $(P=0.044)$, while no other indicators were significant. We then tested the consistency of this result by introducing biogeographic region (Atlantic vs Continental) and fen type (floating fen, rich fen and alkaline spring) to the GLM and allowing interactions between the four predictors. The best model, judged from test statistics and minimization of cross-validation errors, included all four terms and the interaction

Table 2. The best GLM model with Poisson distributed errors for prediction of the number of typical species per vegetation plot. The table reports deviance explained by predictor variable, residual $\mathrm{df}$, residual deviance and $P$-value based on a chi-squared test.

\begin{tabular}{lrrrr}
\hline Predictor & Deviance & Residual $d f$ & $\begin{array}{l}\text { Residual } \\
\text { deviance }\end{array}$ & P-value \\
& & & 7312.8 & \\
\hline NULL model & 81.8 & 2165 & 7231.0 & $<0.001$ \\
Region & 66.3 & 2163 & 7164.6 & $<0.001$ \\
Fen type & 4018.1 & 2162 & 3146.5 & $<0.001$ \\
Nutrient ratio & 80.5 & 2161 & 3066.1 & $<0.001$ \\
Vegetation height & 60.7 & 2160 & 3005.4 & $<0.001$ \\
Nutrient ratio $\times$ & & & & \\
$\quad$ Vegetation height & & & & \\
\hline
\end{tabular}

between nutrient ratio and vegetation height, with nutrient ratio accounting by far for the majority of the deviance explained (Table 2).

\section{Precision of indicators}

Among the significant indicators, the Ellenberg-derived indicators showed very high precision, with between-year variation well below 10\% (Table 1). The number of typical species showed higher variation (28\%). Among the abiotic indicators, $\mathrm{pH}$ was very precise, followed by tissue $\mathrm{N}$, whereas nitrate in water was highly imprecise. The structural parameters, vegetation height and trees below and above $1 \mathrm{~m}$ were all highly imprecise.

\section{Transferability}

Under the expectation that managers would prefer to express the conservation value of a site in terms of typical species rather than a decimal number indicating the nutrient pollution of the fen, we have developed a simple transfer model. Based on the scatter plot (Appendix S3) of typical species in response to nutrient ratio, we suggest that the number of typical species can be predicted most effectively as a piece-wise linear model with a knot placed at a nutrient ratio of 0.75 , resulting in the following model formula:

$$
\begin{aligned}
\text { Typical species }= & 4.35-(\mathrm{NR}-0.75) \times 64, \\
& \text { for nutrient ratio } \leq 0.75
\end{aligned}
$$


Typical species $=4.35-(\mathrm{NR}-0.75) \times 18.2$, for nutrient ratio $>0.75$

This model has an $r^{2}$ of 0.54 , compared to 0.48 for a linear model with a single slope. It appears to be justified to use this simpler model, as the inclusion of vegetation height, region and fen type only increase the $r^{2}$ to 0.59 . The model can only be used in alkaline wetlands, as acidic meadows, mires and bogs are not considered in this study.

\section{Monitoring costs}

The methods used for analysis of nutrients in plant tissue and water are expensive compared to recording of species and measurements of structural parameters in the field (Table 1). Measuring $\mathrm{pH}$ and soil $\mathrm{P}$ is not as costly as making a species list. The floristic indicators all originate from the same list of species, providing seven potential indicators in one measurement.

\section{Discussion}

\section{Selection of endpoint for conservation status}

We selected the number of typical species as a response variable for the evaluation of structural and functional indicators for conservation status. The Habitats Directive does not provide an unambiguous indicator of favourable conservation status, but it is recommended to base the evaluation on typical species as well as structure and function, distribution and range and future prospects (EC Habitats Directive 1992). We only deal with evaluation of local occurrences here, and given that the objective of the Directive is the conservation of biological diversity, we find it well justified to use typical species as a response variable.

\section{Indicators of conservation status}

Nutrient ratio shows the strongest correlation with typical species, followed by E-nutrient and residual N. All three indicators reflect eutrophication, supporting that nutrient load is one of the most important threats to typical species and that infertile conditions are essential for achieving favourable conservation status in groundwater-fed fens and springs. This result is in agreement with several studies of species composition and nutrient availability in fens and springs (Boyer \& Wheeler 1989; Moore et al. 1989; Bedford et al. 1999; Pauli et al. 2002).

The study finds that E-light is strongly correlated with the number of typical species. This result is supported by a study of light as an environmental filter (Kotowski \& van Diggelen 2004), which concluded that light is the most important plant-distributing factor in wetlands. However, our study also finds that E-light correlates even more strongly with E-nutrient than with typical species (Rho $=-0.66, P<0.0001)$, suggesting that the light indicator reflects nutrient status as well as management by mowing or grazing. E-reaction correlates significantly with number of typical species (Rho $=-0.32, P<0.0001$ ), whereas $\mathrm{pH}$ does not (Rho $=0.007$, n.s.). This is quite contradictory, since E-reaction should reflect plant preferences for $\mathrm{pH}$, and these are indeed significantly correlated (Rho $=0.44, P<0.0001)$. The significant negative correlation with typical species may therefore be caused by the strong correlation between E-nutrient and E-reaction $($ Rho $=0.77, P<0.0001)$.

The study did not support previous findings that $\mathrm{pH}$ may explain a significant amount of variation in plant species composition in different fen types (Hájek \& Hekera 2004). The lack of correlation may have two major causes. First, our study does not include poor fen types, limiting the length of the $\mathrm{pH}$ gradient under study. Second, while $\mathrm{pH}$ is largely invariant to eutrophication, species typical of rich fen vegetation are known to be highly sensitive to raised nutrient availability (Bedford et al. 1999; Bergamini \& Pauli 2001). Water content of nitrate showed a very poor correlation with typical species, again in correspondence with the study of Hájek \& Hekera (2004), who found $\mathrm{N}-\mathrm{NO}_{3}^{-}$and $\mathrm{PO}_{4}^{3-}$ in water explained very little of the variation in plant species composition. In contrast, the $\mathrm{N}$ tissue content showed a fairly good correlation with typical species. Willby et al. (2001) found that $\mathrm{N}$ tissue content differed according to plant strategy, with communities dominated by stress-tolerant species having the lowest $\mathrm{N}$ content. The value of tissue nutrient content as an indicator of conservation status might be enhanced by including tissue P. Several studies thus use tissue nutrient content in order to describe ecological conditions, e.g. nutrient limitation based on N:P ratio (Koerselman \& Meuleman 1996; Güsewell et al. 2005; Rozbrojová \& Hájek 2008).

We did not find a significant correlation between conservation status and the available soil P content. This result is contradictory to many previous studies, where the amount of P in soil, water or tissue influenced species composition. For example, effects of $\mathrm{P}$ enrichment have been demonstrated on competitive ability within bryophyte communities (Kooijman \& Paulissen 2006), and P limitation has been shown to be more important than $\mathrm{N}$ limitation in sustaining endangered plant species in wetlands (Wassen et al. 2005). The lack of correlation in our study may be partly explained by the relatively few soil samples taken (measurements in 10\% of all rich fen plots).

Vegetation height correlates negatively with typical species but correlates almost as well with E-nutrient (see Appendix S2). Vegetation height reflects both soil fertility and management (mowing and grazing). This result is thus 
in agreement with the proposal that E-nutrient should be seen as an indicator of productivity rather than $\mathrm{N}$ per se (Hill \& Carey 1997; Schaffers \& Sýkora 2000). The cover of trees below 1-m high correlates positively with typical species, whereas the correlation between taller trees and typical species is negative. This appears to be a quite contradictory result, since most typical species are highly light-demanding according to their E-light values, and a consistent negative influence of tree cover on the typical fen species was expected. The scatterplot of Appendix S3 suggests that the real relationship may rather be unimodal and decreasing at the highest cover values. We suggest that the positive correlation with a moderate cover of smaller trees is an effect of recent abandonment in some of the best fens. Abandonment may be explained by the marginal production value of these fens due to a high water table and a remote geographical position relative to a farm. There may be a considerable time lag between abandonment, bush encroachment and disappearance of the typical species.

\section{Sources of variation in measurements}

Precision of an indicator is of obvious importance. The extent of the NOVANA programme implies that it is impossible to avoid temporal and spatial variation in sampling. The monitoring programme is based on a maximum of one annual sampling of each plot, and while the monitoring of a plot takes place within a time-frame of a few months, it is not necessarily repeated within the same week from $1 \mathrm{yr}$ to another. Furthermore, the monitoring of repeated plots is conducted using a handheld GPS and not permanently marked plots. The accuracy of the handheld GPS is dependent on cloud and tree cover and can vary from 1 to $10 \mathrm{~m}$ (Schwieger 2003).

Nutrient availability in soil and water depends on preceding weather events and timing of the growing season. Measurements may vary significantly temporally, even when samples are taken from exactly the same spot (Hájek \& Hekera 2004), but within-site variation may also be significant over very short distances (Boyer \& Wheeler 1989). Measuring tree cover is based on subjective estimation and, therefore, is likely to vary with the person in charge. The recording of species in the plots should have limited variation, but calibration of species list collection by different observers has revealed that differences in the completeness of species lists are inevitable. Furthermore, the occurrence of single species in plots is far from predictable, but includes a considerable stochastic element (Ejrnæes 2000).

The indicators are evaluated based on circular plots with a radius of $5 \mathrm{~m}$, corresponding to ca. $78.5 \mathrm{~m}^{2}$. When selecting the size of the monitoring plot, there is a trade-off between being representative and being precise (Økland
1990). Small monitoring units contain high precision but are less representative and imply larger variations if not marked permanently. Larger monitoring units reduce the risk of bias in the data, but at the same time the precision of the measurements decreases.

Here, it is found that the size corresponds to the objective of the study: the habitats may be adequately described while still retaining the precision required for making conclusions on habitats characterized by considerable finescale environmental variation.

\section{Precision of indicators}

All indicators derived from Ellenberg values were found to be stable (variation $<10 \%$ ). The indicator value is based on the average of all species present and is thus less sensitive to temporal and spatial variation of the species lists. The stochastic variation in the exact occurrence of different taxa is reduced when species are represented as Ellenberg numbers, because species may have the same ecological preferences. Further, Ellenberg numbers are averaged over all species on the list, which reduces the impact on the indicator of variation in the completeness of the species list. In contrast, the number of typical species is not very stable over years compared to the derived indicators. The small-scale variability of spring and rich fen habitats (Boyer \& Wheeler 1989) implies that moving the plot a few meters may result in sampling a different species composition. Further, stochastic differences in species occurrences, as well as differences in the skill of the observer, may add to the variability in number of typical species. The high precision of $\mathrm{pH}$ is in accordance with the results of Hájek \& Hekera (2004), who found that pH and electrical conductivity were very stable variables. The stability of $\mathrm{N}$ tissue content lies between the very stable and the very unstable indicators. The nutrient content of tissue is dependent on season, and the monitoring season may extend from May to September, implying some natural variation in the data (Willby et al. 2001). Nitrate in water is a highly unstable variable, probably due to the rapid turnover. Unless $\mathrm{N}$ is bound to organic matter it is easily dissolved when water is present, and nitrate in water is rapidly immobilized through plants and microorganisms. Furthermore, fens and springs are through-flow habitats with continuous in- and outflow of water. Nitrate content will therefore show large temporal variations according to patterns of rainfall and seasonal growing conditions. A study of seasonal variation of chemistry in fen water revealed that $\mathrm{N}-\mathrm{NO}_{3}^{-}$and also $\mathrm{PO}_{4}^{-}$varied considerably and only poorly explained the variation in plant species composition (Hájek \& Hekera 2004). Vegetation height and tree cover are, together with nitrate water content, the least precise indicators. The high instability of the three 
structural parameters can be related to major changes in management or land use from year-to-year, or, more plausible, habitats are so variable on a small spatial scale that GPS uncertainty induces large variation (Boyer \& Wheeler 1989).

\section{Cost-efficiency of indicators}

The most remarkable difference in cost is that measuring species produces four to five valuable indicators of conservation status, whereas analysing water, soil and tissue samples produces only one significant and simultaneously less precise indicator with a lower accuracy. The overall best indicator was the nutrient ratio, calculated by dividing E-nutrient by E-reaction, and we have shown in a transfer model how this indicator can be used to estimate the expected number of typical species. This indicator incorporates the correlation between $\mathrm{pH}$ and soil fertility that whether successfully experimentally shown or not - is integrated in the Ellenberg values (Waughman 1980; Verhoeven et al. 1990; Vitt \& Chee 1990; Bridgham et al. 1998; Aerts et al. 1999; Bedford et al. 1999) and produces an indicator of eutrophication that appears to work well within the environmental range of Danish rich fen and alkaline spring vegetation.

\section{Conclusions}

Indicator-based assessment of conservation status requires accurate and precise indicators that effectively reflect the status of the habitat. This study finds that vegetationderived indicators of conservation status in rich fens and springs are more robust and cost-efficient than structural and abiotic parameters. Nutrient ratio as a measure of conservation status in alkaline wetlands should be applicable over major European regions. Since eutrophication is one of the largest threats to fen conservation, nutrient ratio can provide a valuable and comparable tool in management.

\section{Acknowledgements}

Two anonymous reviewers are thanked for valuable suggestions on data analysis and presentation of results. The work was supported by a grant from the 15. Juni fonden.

\section{References}

Aerts, R., Verhoeven, J.T.A. \& Whigham, D.F. 1999. Plant-mediated controls on nutrient cycling in temperate fens and bogs. Ecology 80: 2170-2181.

Almendinger, J. \& Leete, J. 1998a. Regional and local hydrogeology of calcareous fens in the Minnesota River basin, USA. Wetlands 18: 184-202.
Almendinger, J.E. \& Leete, J.H. 1998b. Peat characteristics and groundwater geochemistry of calcareous fens in the Minnesota River Basin, U.S.A. Biogeochemistry 43: 17-41.

Amon, J., Thompson, C., Carpenter, Q. \& Miner, J. 2002. Temperate zone fens of the glaciated Midwestern USA. Wetlands 22: 301-317.

Anon. 1991. CORINE biotopes manual, habitats of the European Community. EUR 12587/3, Office for Official Publications of the European Communities, Luxembourg, LX.

Bedford, B.L., Walbridge, M.R. \& Allison, A. 1999. Patterns in nutrient availability and plant diversity of temperate North American wetlands. Ecology 80: 2151-2169.

Bergamini, A. \& Pauli, D. 2001. Effects of increased nutrient supply on bryophytes in montane calcareous fens. Journal of Bryology 23: 331-339.

Boeye, D. \& Verheyen, R.F. 1992. The hydrological balance of a groundwater discharge fen. Journal of Hydrology 137: 149163.

Boomer, K. \& Bedford, B. 2008. Groundwater-induced redoxgradients control soil properties and phosphorus availability across four headwater wetlands, New York, USA. Biogeochemistry 90: 259-274.

Boyer, M.L.H. \& Wheeler, B.D. 1989. Vegetation patterns in spring-fed calcareous fens: calcite precipitation and constraints on fertility. Journal of Ecology 77: 597-609.

Bragazza, L., Gerdol, R. \& White, P.S. 2002. Are nutrient availability and acidity-alkalinity gradients related in Sphagnum-dominated peatlands? Journal of Vegetation Science 13: 473-482.

Bridgham, S., Pastor, J., Janssens, J., Chapin, C. \& Malterer, T. 1996. Multiple limiting gradients in peatlands: a call for a new paradigm. Wetlands 16: 45-65.

Bridgham, S.D., Updegraff, K. \& Pastor, J. 1998. Carbon, nitrogen, and phosphorus mineralization in northern wetlands. Ecology 79: 1545-1561.

Bridgham, S.D., Updegraff, K. \& Pastor, J. 2001 . A comparison of nutrient availability indices along an ombrotrophic-minerotrophic gradient in Minnesota wetlands. Soil Science Society of America Journal 65: 259-269.

Council of European Communities. 1999. Interpretation manual of European Union habitats. EUR 15/2. October 1999. Council of European Communities, Brussels, BE.

Diekmann, M. 1995. Use and improvement of Ellenberg's indicator values in deciduous forests of the Boreo-nemoral zone in Sweden. Ecography 18: 178-189.

Diekmann, M. 2003. Species indicator values as an important tool in applied plant ecology - a review. Basic and Applied Ecology 4: 493-506.

Diekmann, M. \& Falkengren-Grerup, U. 1998. A new species index for forest vascular plants: development of functional indices based on mineralization rates of various forms of soil nitrogen. Journal of Ecology 86: 269-283.

EC Habitats Directive. 1992. Council Directive 92/43/EEC of 21 May 1992 on the conservation of natural habitats and of wild fauna and flora. EC Habitats Directive, Brussels, BE. 
Ejrnæs, R. 2000. Can we trust gradients extracted by detrended correspondence analysis? Journal of Vegetation Science 11: 565-572.

Ejrnæe, R., Nygaard, B., Fredshavn, J., Nielsen, K. \& Damgaard, C. 2009. Faglig rapport fra DMU nr. 712 TERRESTRISKE NATURTYPER 2007 NOVANA.

Ellenberg, H., Weber, H.E., Düll, R., Wirth, V., Werner, W. \& Paulißen, D. 1991. Zeigerwerte von Pflanzen in Mitteleuropa. Scripta Geobotanica 18: 9-160.

Grootjans, A.P., Adema, E.B., Bleuten, W., Joosten, H., Madaras, M. \& Janikoví, M. 2006. Hydrological landscape settings of base-rich fen mires and fen meadows: an overview. Applied Vegetation Science 9: 175-184.

Güsewell, S., Bailey, K.M., Roem, W.J. \& Bedford, B.L. 2005. Nutrient limitation and botanical diversity in wetlands: can fertilisation raise species richness? Oikos 109: 71-80.

Hájek, M. \& Hekera, P. 2004. Can seasonal variation in fen water chemistry influence the reliability of vegetation-environment analyses? Preslia 76: 1-14.

Heathwaite, A.L. 1990. The effect of drainage on nutrient release from fen peat and its implications for water quality - a laboratory simulation. Water, Air and Soil Pollution 49: 159-173.

Hill, M.O. \& Carey, P.D. 1997. Prediction of yield in the Rothamsted Park grass experiment by Ellenberg indicator values. Journal of Vegetation Science 8: 579-586.

Hill, M.O., Mountford, J.O., Roy, D.B. \& Bunce, R.G.H. 1999. Ellenberg's indicator values for British plants. ECOFACT. Vol. 2. Technical annex. Institute of Terrestrial Ecology, Huntingdon, UK.

Joint Committee for Guides in Metrology. 2008. International Vocabulary of Meteorology: Basic and General Concepts and Associated Terms, VIM.

Koerselman, W. \& Meuleman, A.F.M. 1996. The vegetation N:P ratio: a new tool to detect the nature of nutrient limitation. Journal of Applied Ecology 33: 1441-1450.

Kooijman, A.M. \& Paulissen, M.P.C.P. 2006. Higher acidification rates in fens with phosphorus enrichment. Applied Vegetation Science 9: 205-2 12.

Kotowski, W. \& van Diggelen, R. 2004. Light as an environmental filter in fen vegetation. Journal of Vegetation Science 15:583-594.

Large, A.R.G., Mayes, W.M., Newson, M.D. \& Parkin, G. 2007. Using long-term monitoring of fen hydrology and vegetation to underpin wetland restoration strategies. Applied Vegetation Science 10: 417-428.

Leith, I.D., van Dijk, N., Pitcairna, C.E.R., Wolseley, P.A., Whitfield, C.P. \& Sutton, M.A. 2005. Biomonitoring methods for assessing the impacts of nitrogen pollution: refinement and testing. JNCC Report 386.

Mälson, K., Backéus, I. \& Rydin, H. 2007. Long-term effects of drainage and initial effects of hydrological restoration on rich fen vegetation. Applied Vegetation Science 11: 99-106.

Moore, D.R.J., Keddy, P.A., Gaudet, C.L. \& Wisheu, I.C. 1989. Conservation of wetlands: do infertile wetlands deserve a higher priority? Biological Conservation 47: 203-217.
Nimis, P.L. \& Martellos, S. 2001. Testing the predictivity of ecological indicator values. A comparison of real and 'virtual' relevés of lichen vegetation. Plant Ecology 157: 165-172.

Økland, R.H. 1990. Vegetation ecology: theory, methods and applications with reference to Fennoscandia. Sommerfeltia Supplement. 1: 1-233. ISBN 8274200063, 9788274200067.

Påhlsson, L. 1994. Vegetationstyper i Norden. TemaNord 1994: 665. Nordiska Ministerrådet, Köpenhamn, NO.

Pauli, D., Peintinger, M. \& Schmid, B. 2002. Nutrient enrichment in calcareous fens: effects on plant species and community structure. Basic and Applied Ecology 3: 255-266.

Rozbrojová, Z. \& Hájek, M. 2008. Changes in nutrient limitation of spring fen vegetation along environmental gradients in the West Carpathians. Journal of Vegetation Science 19: 613-620.

Schaffers, A.P. \& Sýkora, K.V. 2000. Reliability of Ellenberg indicator values for moisture, nitrogen and soil reaction: a comparison with field measurements. Journal of Vegetation Science 11: 225-244.

Schwieger, V. 2003. TS12 Positioning and Measurement Technologies and Practices TS12.1 Using Handheld GPS Receivers for Precise Positioning, 2nd FIG Regional Conference Marrakech, MA, December 2-5, 2003.

Seidling, W. 2005. Ground floor vegetation assessment within the intensive (Level II) monitoring of forest ecosystems in Germany: chances and challenges. European Journal of Forest Research 124: 301-312.

Svendsen, L.M. \& Norup, B. (eds.) 2005. NOVANA. Nationwide monitoring and assessment programme for the aquatic and terrestrial environments. Programme description - part 1. National Environmental Research Institute, DK. NERI Technical Report No. 532.

Svendsen, L.M., van der Bijl, L., Boutrup, S. \& Norup, B. (eds.) 2005. NOVANA. National monitoring and assessment programme for the aquatic and terrestrial environments. Programme Description - Part 2. National Environmental Research Institute, DK. NERI Technical Report No. 537.

Ter Braak, C.J.F. \& Gremmen, N.J.M. 1987. Ecological amplitudes of plant species and the internal consistency of Ellenberg's indicator values for moisture. Vegetatio 69: 79-87.

van Haesebroeck, V., Boeye, D., Verhagen, B. \& Verheyen, R.F. 1997. Experimental investigation of drought induced acidification in a rich fen soil. Biogeochemistry 37: 15-32.

Verhoeven, J.T.A., Maltby, E. \& Schmitz, M.B. 1990. Nitrogen and phosphorus mineralization in fens and bogs. Journal of Ecology 78: 713-726.

Vitt, D.H. \& Chee, W.L. 1990. The relationships of vegetation to surface water chemistry and peat chemistry in fens of Alberta, Canada. Vegetatio 89: 87-106.

Wamelink, G.W.W., Joosten, V., van Dobben, H.F. \& Berendse, F. 2002. Validation of Ellenberg indicator values judged from physico-chemical field measurements. Journal of Vegetation Science 13: 269-278.

Wassen, M.J. \& Olde Venterink, H. 2006. Comparison of nitrogen and phosphorus fluxes in some European fens and floodplains. Applied Vegetation Science 9: 213-222. 
Wassen, M.J., Venterink, H.O., Lapshina, E.D. \& Tanneberger, F. 2005. Endangered plants persist under phosphorus limitation. Nature 437: 547-550.

Waughman, G.J. 1980. Chemical aspects of the ecology of some south German peatlands. Journal of Ecology 68: 1025-1046.

Wheeler, B.D. \& Proctor, M.C.F. 2000. Ecological gradients, subdivisions and terminology of North-West European mires. Journal of Ecology 88: 187-203.

Willby, N.J., Pulford, I.D. \& Flowers, T.H. 2001. Tissue nutrient signatures predict herbaceous-wetland community responses to nutrient availability. New Phytologist 152: 463-481.

\section{Supporting information}

Additional Supporting Information may be found in the online version of this article:

Appendix S1. List of typical species.

Appendix S2. Matrix of all rank correlations between indicators.

Appendix S3. Graphs showing the distribution of typical species in relation to the different indicators. 


\section{Graphical Abstract}

The contents of this page will be used as part of the graphical abstract of html only. It will not be published as part of main.

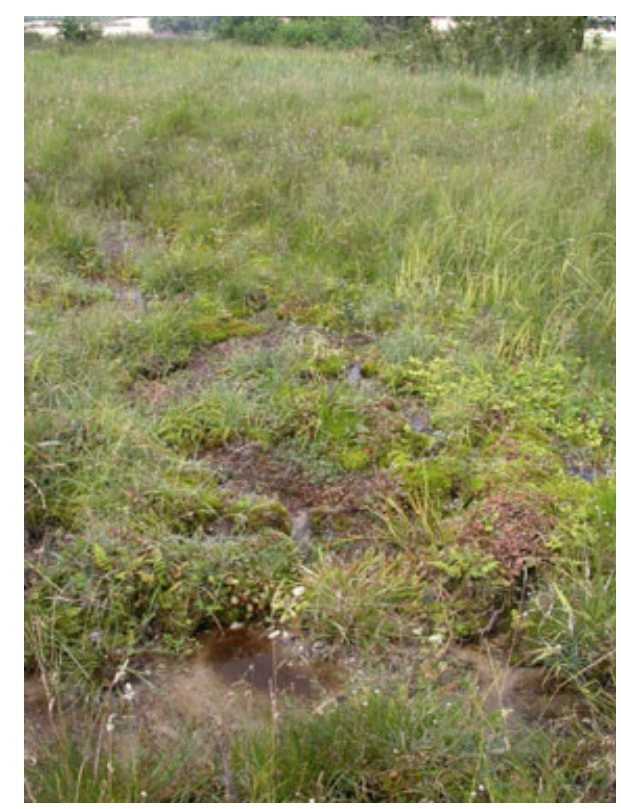

Different indicators of conservation status in rich fens and alkaline springs were evaluated based on accuracy (ability to predict number of typical species), precision (variation over years) and cost. We found that biotic indices based on Ellenberg indicator values, particularly the ratio between Ellenberg Nutrient and Ellenberg Reaction, outperformed chemical and structural indicators. 